\title{
ANALISIS PRODUKTIVITAS DAN PENDAPATAN PADA USAHA TERPADU JAGUNG-SAPI
}

\author{
LAODE MUH MUNADI \\ PASCASARJANA ILMU PERTANIAN, UNIVERSITAS HALU OLEO \\ KENDARI, SULAWESI TENGGARA \\ email: Immunadi@gmail.com
}

\begin{abstract}
BAB I
PENDAHULUAN

Peran sektor pertanian dalam pembangunan berkelanjutan dapat dilihat dari kontribusi sektor pertanian terhadap perekonomian nasional. Sektor pertanian terdiri dari subsektor tanaman pangan, holtikultura, kehutanan, perkebunan dan peternakan, diantara keempat subsektor yang memiliki peran penting, sektor panganlah yang memiliki peran penting dalam penyediaan bahan pangan bagi masyarakat dalam menunjang keberlangsungan hidup. Tanaman pagan terdiri dari dua kelompok besar yaitu padi dan palawija, tanaman palawija juga diarahkan dalam ketahanan pangan serta pengentasan kemiskinan. Tanaman palawija yang banyak dibudidayakan oleh petani adalah tanaman jagung.

Sistem pertanian terpadu telah menjadi bagian dari budaya bertani di Indonesia. Sistem ini mampu memanfaatkan sumber daya lokal yaitu bahan ikutan berupa jerami, serta kotoran ternak secara efisien. Ciri utama sistem pertanian terpadu adalah adanya keterkaitan antara tanaman dan ternak misalnya limbah tanaman jagung (jerami) digunakan sebagai pakan ternak, begitupun sebaliknya kotoran ternak dapat digunakan sebagai pupuk organik untuk tanaman. Sistem pertanian terpadu memberikan keuntungan kepada petani yaitu pupuk kandang sapi dan bahan ikutan pertanian berupa jerami. Pupuk kandang sapi selama ini belum optimal digunakan dapat dimanfaatkan sebagai pupuk organik untuk meningkatkan kesuburan tanah atau dapat dijual sebagai sumber pendapatan. Limbah pertanian yang tersedia dapat dimanfaatkan sebagai sumber pakan yang berkualitas, sehingga mengurangi biaya penyediaan pakan. Sistem pertanian terpadu merupakan solusi terhadap permasalahan pakan dapat memperkuat ketahanan pangan dengan pengolahan limbah pertanian menjadi pakan bernilai nutrisi tinggi dan dapat mencukupi kebutuhan ternak sapi. Secara umum, sistem pertanian terpadu merupakan salah satu cara bangsa Indonesia untuk mewujudkan ketahanan, kemandirian, dan kedaulatan pangan.

Sistem terpadu jagung ternak merupakan konsep pengembangan pertanian dalam memandang usahatani sebagai suatu sistem. Hal ini, merupakan keterkaitan antar cabang usahatani, baik itu dalam penggunaan input maupun dalam tingkat output yang dihasilkan. Sistem pertanian terpadu jagung ternak merupakan model yang digunakan oleh sebagian petani, baik dalam bentuk tradisional maupun yang telah modern. Sistem pertanian terpadu mampu memanfaatkan sumber daya lokal dari usahatani jagung dan ternak sapi potong dengan bentuk kotoran sapi dan jerami. Pemanfaatan kotoran sapi sebagai pupuk organik untuk tanaman jagung dan limbah jagung berubah jerami sebagai tambahan pakan ternak sapi potong merupakan ciri dari penerapan sistem integrasi ini. Melalui kombinasi ini diharapkan mampu meningkatkan kesejahateraan masyarakat dalam penghematan biaya serta penambahan jumlah penerimaan dari dua sumber yakni
\end{abstract}


hasil produksi jagung dan hasil jual ternak. Oleh karena itu, pengembangan sistem integrasi jagung-ternak merupakan pendekatan agribisnis penting untuk diterapkan sebab melalui kombinasi kotoran sapi dan jerami jagung akan mampu memberikan manfaat bagi petani.

Pola usahatani integrasi tanaman dengan ternak dapat memberikan kontribusi sekaligus manfaat besar bagi petani, sebab petani dapat memanfaatkan pupuk organik yang dihasilkan ternak untuk memupuk tanaman. Hasil ikutan pertanian berupa jerami, jagung, dapat dimanfaatkan petani sebagai pakan ternak. Pola terpadu tanaman dan ternak mampu menekan biaya produksi sehingga pendapatan petani dapat ditingkatkan. Berdasarkan latar belakang maka makalah yang diformulasikan pada judul analisis produktivitas dan pendapatan pada usaha terpadu jagung-sapi.

\section{BAB II TINJAUAN PUSTAKA}

\subsection{Sistem Pertanian Terpadu}

Pembangunan berkelanjutan mencakup beberapa aspek, berupa aspek ekologis, ekonomi, sosial budaya, lingkungan, politik, serta pertahanan dan keamanan. Konsep pertanian terpadu yang melibatkan tanaman dan ternak sebenarnya sudah diterapkan oleh petani di Indonesia sejak mereka mengenal pertanian, namun masih secara tradisional, tanpa memperhitungkan untung-rugi, baik secara finansial maupun dalam konteks pelestarian lingkungan hidup (Usman et al., 2017). Sistem pertanian terpadu merupakan sistem kombinasi berbagai spesies tanaman dan hewan serta penerapan beraneka ragam dalam menciptakan kondisi yang sesuai untuk melindungi lingkungan, juga membantu petani menjaga produktivitas lahan sekaligus meningkatkan pendapatan mereka dengan adanya diversifikasi usaha tani (Jurhadi Kadir, 2020; Hidayati et al., 2020).

Sistem pertanian terpadu menyediakan beragam produk yang lebih besar ke keluarga petani dan menawarkan cara untuk memanfaatkan residu tanaman atau lahan non-pertanian untuk menghasilkan produk terkait, sekaligus menghasilkan pupuk kandang untuk memperbaiki kesuburan dan kualitas tanah yang dibudidayakan (Basuni \& Kusmana, 2015; Fyka et al., 2019). Sistem pertanian terpadu merupakan intensifikasi sistem usahatani melalui pengelolaan sumberdaya alam dan lingkungan secara terpadu dengan komponen ternak sebagai bagian kegiatan usaha (Merakati et al., 2017; Kurniati et al., 2019). Pengelolaan tanaman terpadu merupakan pendekatan inovatif yang berupaya meningkatkan produktivitas usahatani dan mempertahankan keberlanjutan pemanfaatan lahan bagi usahatani (Iskandar \& Nurtilawati, 2019).

Pertanian terpadu tanaman-ternak dapat memperbaiki kualitas tanah, meningkatkan hasil, menghasilkan pangan beragam dan memperbaiki efisiensi penggunaan lahan. Manfaat pertanian terpadu tanaman-ternak yaitu aspek agronomi untuk peningkatan kapasitas tanah, aspek ekonomi yaitu diversifikasi produk, aspek ekologi yaitu menurunkan serangan hama dan penggunaan pestisida, dan aspek sosial yaitu distribusi pendapatan lebih merata (Suwarto et al., 2019). Pertanian terpadu yakni kombinasi tanaman-ternak, jumlahnya bisa sangat banyak. Ketika, dihadapkan pada alternatif dan perlu ada suatu model perancangan untuk menentukan pilihan pola pertanian terpadu yang optimal secara ekologis dan ekonomis (Tumewu et al., 2014; Kemala \& Sekartika, 2019).

Kemandirian pangan determinan lingkungan perekonomian yang stabil dan kondusif bagi pembangunan (Nazam et al., 2016). Kemandirian pangan identik dengan konsep swasembada pangan yang saat ini menjadi salah satu target pembangunan pertanian 
(Khairad, 2020). Upaya dalam pembangunan di sektor pertanian yaitu dengan meningkatkan lahan pertanian tanaman pangan, semakin meningkatnya lahan pertanian tanaman pangan akan berimplikasi pada meningkatnya produksi limbah. Pengembangan peternakan sangat terkait dengan pengembangan suatu wilayah. Karena merupakan bagian dari potensi cukup besar untuk pengembangan peternakan (Zahara et al., 2016; Hanifa \& Sari, 2017).

Pakan memiliki peranan penting bagi ternak, baik untuk pertumbuhan ternak muda maupun untuk mempertahankan hidup serta tenaga bagi ternak dewasa (Aziz et al., 2014). Pakan mengandung nilai gizi cukup dapat meningkatkan produktivitas pembibitan sapi lebih optimal (Sari et al., 2016). Dalam operasionalnya pelaksanaan pembangunan pertanian di tingkat petani pada umumnya masih bersifat parsial (per subsektor), sehingga petani sebagai pelaku usaha tani dikelompokkan menjadi petani tanaman pangan, hortikultura, ikan, ternak, dan perkebunan (Tarmizi \& Safaruddin, 2015). Mengelola secara berkelanjutan kelembagaan ekonomi yang melaksanakan praktik terbaik dan kepemerintahan yang baik, dan mengelola secara berkelanjutan sumber daya alam sesuai kompetensi dan keunggulan daerah (Susanto, 2014).

Penerapan pertanian terpadu Sapi potong-jagung merupakan sumber daya penghasil yang memiliki nilai ekonomis yang tinggi dan penting dan artinya di dalam kehidupan masyarakat (Sasoeng et al., 2020). Usaha peternakan yang banyak dilakukan oleh masyarakat pedesaan adalah beternak sapi potong yang berbentuk usaha peternakan rakyat yang masih secara tradisional (Zebedeus et al., 2018). Usaha penggemukan sapi potong harus dapat mengatasi permasalahan di tingkat hulu sampai tingkat hilir, dengan demikian upaya perbaikan perlu di lakukan di setiap subsistem agribisnis dengan penyediaan sumber pakan (Mutmaidah, 2018).

\subsection{Sistem Terpadu Jagung-Sapi Potong}

Sistem integrasi tanaman pertanian dan ternak sapi dicirikan oleh adanya keterkaitan antara tanaman dengan ternak. Hasil tanaman pertanian untuk pangan, jerami sebagai pakan misalnya jerami jagung manis (Lukiwati et al., 2016). Ketersediaan pakan secara kontinyu dan berkualitas merupakan faktor pembatas pengembangan sapi potong, karena keterbatasan lahan untuk budidaya tanaman pakan (Dewi, 2019). Jagung merupakan salah satu komoditas tanaman pangan yang berpeluang sebagai sumber lapangan kerja dan pendapatan petani, sekaligus menopang program ketahanan pangan di perdesaan. Jagung dapat menjadi bahan pangan alternatif penghasil karbohidrat setelah padi, juga sebagai bahan baku industri makanan ringan maupun pakan ternak (Syafruddin, 2010).

Lahan sempit merupakan kendala utama dalam upaya peningkatan pendapatan petani sehingga lahan tersebut harus dimanfaatkan secara maksimal. Mengusahakan lahan dengan berbagai komponen jenis tanaman dan ternak secara terintegrasi. Salah satu bentuknya adalah sistem integrasi jagung pulut-sapi, di mana jagung menghasilkan bahan pangan dan brangkasan untuk pakan sapi, sebaliknya sapi menghasilkan pupuk kandang untuk jagung (Suwarto \& Prihantoro, 2020). Hal ini merupakan pendekatan yang sesuai untuk keberlanjutan produksi, pendapatan, serta membuka kesempatan kerja bagi rumah tangga petani di perdesaan yang berlahan sempit (Paramuji \& Sunarti, 2012).

Sistem usahatani integrasi jagung-sapi menentukan keberhasilan produk yang bisa bersaing, sekaligus membuka peluang kerja serta memberikan pendapatan bagi petani. Hal ini ditujukan dalam meningkatkan ketahanan pangan serta ketersediaan pakan ternak sapi yang diarahkan untuk dapat memenuhi kebutuhan ekonomi masyarakat dari produksi pangan jagung maupun ternak sapi baik secara regional maupun nasional 
(Marjaya, 2016). Integrasi jagung-sapi yang dilaksanakan secara terpadu (integrated farming system), saling mendukung, memperkuat dan saling menguntungkan (Sariubang, 2010). Dengan kata lain tidak ada limbah atau hasil samping yang terbuang percuma.

Potensi limbah pertanian tanaman pangan sangat besar, dan sebagian belum dimanfaatkan sebagai pakan ternak, namun dengan pola sistem integrasi jagung dan sapi dapat menjadi andalan dalam upaya meningkatkan produktivitas tanaman pangan, ternak, sekaligus dapat meningkatkan kesuburan tanah (Rocha Rego et al., 2017). Penerapan sistem pertanian terpadu integrasi ternak dan tanaman terbukti sangat efektif dan efisien dalam rangka penyediaan pangan masyarakat (Asai et al., 2018). Dengan demikian akan dapat meningkatkan produktivitas tanaman maupun ternak, efektif, efisien dalam menggunakan tenaga kerja dan waktu kerja, serta dapat menurunkan biaya produksi (Muchlis \& Nurcholis, 2018). Dengan biaya produksi yang minimum akan diperoleh harga output yang lebih kompetitif.

\section{BAB III \\ METODE ANALISIS DATA}

Analisis usaha jagung manis dan penggemukan sapi dihitung dan dapat dibedakan menjadi: 1) biaya bahan baku; 2) biaya alat produksi yang berusia lama; 3) biaya tenaga kerja; 4) biaya tanah; 5) biaya bunga; serta 6) biaya jasa-jasa pihak lain dan pajak. biaya total merupakan penjumlahan antara biaya tetap dan biaya variabel, secara matematis dirumuskan sebagai berikut:

$\mathrm{TC}=\mathrm{FC}+\mathrm{VC}$

\section{Keterangan:}

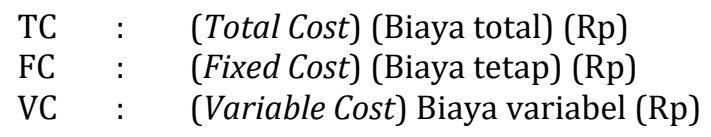

Oleh sebab itu, biaya yang dibutuhkan dalam usaha jagung manis dan penggemukan sapi dapat digolongkan menjadi dua bagian yaitu biaya tetap, Biaya tetap adalah biaya yang sampai batas waktu tertentu tidak berubah. Biaya tetap terdiri atas penyusutan bangunan, pembangunan mekanisasi, peralatan, gaji, pajak, serta asuransi dan lain-lain. Sedangkan untuk biaya variabel adalah biaya yang berhubungan dengan tingkat produksi atau penjualan.

Usaha jagung manis dan penggemukan sapi juga dihitung berdasarkan penerimaan, Penerimaan merupakan nilai atau hasil dari penjualan produk yang dihasilkan dari suatu usaha yang dijalankan. Sementara itu, penerimaan dapat digolongkan kedalam dua kategori yaitu penerimaan tunai dan non tunai. Sedangkan penerimaan merupakan hasil perkalian antara harga jual serta jumlah output, secara matematis dirumuskan sebagai berikut:

$$
\mathrm{TR}=\mathrm{Q} \times \mathrm{Pq}
$$

\section{Keterangan:}

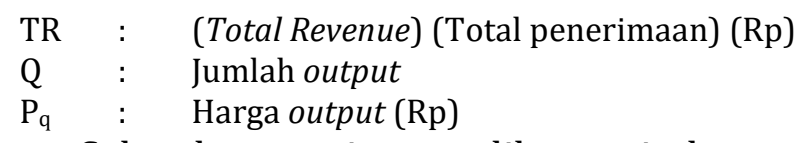

Seluruh penerimaan dikurangi dengan seluruh biaya produksi akan diperoleh keuntungan kotor dan jika keuntungan kotor telah dikurangi pajak dan sejenisnya maka disebut keuntungan bersih. Keuntungan bersih tersebut diartikan sebagai pendapatan.

Pendapatan adalah jumlah yang diperoleh setelah semua biaya tertutupi atau secara sederhana diartikan sebagai selisih antara penerimaan dan biaya. Secara khusus 
pendapatan dikelompokkan menjadi beberapa jenis, antara lain: 1) pendapatan total; 2) pendapatan rata-rata; dan 3) pendapatan marginal. Secara matematis dirumuskan sebagai berikut:

$$
\mathrm{Pq}=\mathrm{TR}+\mathrm{TC}
$$

\section{Keterangan:}

$\begin{array}{lll}\mathrm{P}_{\mathrm{q}} & : & \text { Pendapatan }(\mathrm{Rp}) \\ \mathrm{TR} & : & \text { (Total Revenue) (Total penerimaan) (Rp) } \\ \mathrm{TC} & : & (\text { Total Cost) (Total biaya) (Rp) }\end{array}$

Analisis pendapatan bertujuan diantaranya: 1) memberikan gambaran usaha dimasa sekarang; 2) memberikan gambaran usaha dari perencanaan masa yang akan datang. Bagi seorang petani dan peternak, analisis pendapatan memberikan bantuan untuk mengukur berhasil dan tidaknya kegiatan usaha tani maupun ternak. Analisis pendapatan memerlukan dua keterangan pokok yaitu keadaan penerimaan dan keadaan pengeluaran selama jangka waktu tertentu.

Analisis kelayakan finansial Kelayakan dapat diartikan bahwa usaha yang dijalankan dapat memberikan keuntungan finansial atau non finansial. Sekaligus, menganalisis aspek keuangan dari studi kelayakan dalam menentukan rencana investasi melalui perhitungan biaya dan manfaat yang diharapkan.

Net Present Value (NPV) merupakan nilai saat ini dari selisih antara total benefit serta total cost pada discount rate tertentu selama jangka waktu umur investasi. Net Present Value (NPV) merupakan ukuran yang digunakan untuk mendapatkan hasil neto (net benefit) secara maksimal yang dapat dicapai dengan investasi modal dari sumbersumber lain, untuk menganalisis suatu proyek adalah apabila Net Present Value (NPV) $>0$ berarti investasi menguntungkan atau layak, jika Net Present Value (NPV) $<0$ berarti investasi merugi atau tidak layak, sedangkan Net Present Value (NPV) $=0$ maka investasi pulang pokok. Net Present Value (NPV) mengurangkan nilai sekarang dengan aliran kas bersih operasional atas investasi selama umur ekonomis termasuk terminal cash flow dengan initial cash flow.

Net Benefit Cost Ratio (Net B/C Ratio) adalah perbandingan antara present value dari net benefit negatif. Analisis ini bertujuan untuk mengetahui berapa besarnya keuntungan dibandingkan dengan pengeluaran selama umur ekonomi proyek. Net B/C Ratio merupakan angka yang menunjukan besarnya keuntungan bersih yang diperoleh dari satu rupiah yang diinvestasikan dengan kriteria penilaian suatu kelayakan proyek ditentukan jika Net B/C Ratio $>1$, berarti investasi menguntungkan atau layak dan bila Net B/C Ratio $<1$, berarti investasi tidak menguntungkan atau tidak layak sedangkan Net $\mathrm{B} / \mathrm{C}$ Ratio $=1$, berarti investasi pulang pokok. Sedangkan, Internal Rate of Return (IRR) merupakan tingkat suku bunga yang dapat membuat besarnya nilai Net Present Value (NPV) dari suatu usaha sama dengan nol (0) atau yang dapat membuat nilai Net Benefit Cost Ratio (Net B/C Ratio) sama dengan satu (1) dalam jangka waktu tertentu. Dalam penentuan kelayakan investasi, indikator IRR merupakan perbandingan tingkat bunga uang yang berlaku di Bank, apabila nilai IRR > bunga Bank berarti investasi layak, dan apabila IRR < bunga Bank berarti investasi rugi, sedangkan IRR = bunga Bank berarti investasi pulang pokok. Selanjutnya Break Event Point (BEP) merupakan suatu kondisi pada saat hasil usaha sama dengan modal yang dikeluarkan yaitu kondisi dimana penerimaan sama dengan total modal yang digunakan $(R=C)$. 


\section{BAB IV \\ HASIL DAN PEMBAHASAN}

\subsection{Hasil Analisis Integrasi Jagung Manis dan Penggemukan Sapi Potong}

Jagung merupakan salah satu komoditas tanaman pangan yang berpeluang sebagai sumber lapangan kerja dan pendapatan petani, sekaligus menopang program ketahanan pangan di perdesaan. Jagung dapat menjadi bahan pangan alternatif penghasil karbohidrat setelah padi, juga sebagai bahan baku industri makanan ringan maupun pakan ternak. Usaha tani jagung umumnya belum dikelola secara optimal sehingga produktivitasnya rendah. Modifikasi sistem pertanaman pada usaha tani jagung di lahan kering merupakan salah satu upaya untuk meningkatkan produktivitas lahan dan sekaligus pendapatan petani melalui penganekaragaman produk yang dihasilkan pada satu siklus pertanaman, yaitu biji dan brangkasan (Syafrudin, 2010). Asumsi pada sistem pertanian terpadu jagung manis dan penggemukan sapi disajikan pada Tabel 1.

Tabel 1. Asumsi pertanian terpadu jagung manis dan penggemukan sapi

\begin{tabular}{|c|l|c|l|}
\hline No & \multicolumn{1}{|c|}{ Asumsi } & Satuan & \multicolumn{1}{|c|}{ Nilai / Jumlah } \\
\hline 1 & Periode proyek & Tahun & 5 \\
\hline 2 & Benih jagung manis (Rp. 480.000 per kg) & $\mathrm{Kg} / \mathrm{Ha}$ & 8 \\
\hline 3 & Biaya pengolahan tanah & $\mathrm{Rp} / \mathrm{Ha}$ & 1.500 .000 \\
\hline 4 & Biaya Penanaman & $\mathrm{Rp} / \mathrm{Ha}$ & 1.500 .000 \\
\hline 5 & Biaya Pemupukan (pada awal tanam, umur 14 hari dan 30 hari) & $\mathrm{Rp} / \mathrm{Ha}$ & 1.000 .000 \\
\hline 6 & Populasi jagung layak panen & $\mathrm{Tkl} / \mathrm{Ha}$ & 38.000 \\
\hline 7 & Harga jual per tongkol & $\mathrm{Rp} / \mathrm{Tkl}$ & 2.000 \\
\hline 8 & Umur panen & Hari & 70 \\
\hline 9 & Jumlah kali panen & Kali/Thn & 4 \\
\hline 10 & Tenaga kerja keluarga & Orang & 5 \\
\hline
\end{tabular}

Hasil analisis pada Tabel 1. Menunjukkan bahwa untuk komponen-komponen dalam asumsi pertanian terpadu jagung manis dan ternak sapi potong terdapat Komponen biaya terbesar adalah pengolahan lahan, biaya penanaman sebesar Rp. 1.500.000 dan biaya pemupukan sebesar Rp. 1.000.000. Komponen investasi sistem pertanian terpadu jagung manis dan penggemukan sapi disajikan pada Tabel 2.

Tabel 2. Komponen investasi pertanian terpadu jagung manis dan penggemukan sapi

\begin{tabular}{|r|l|c|c|c|c|}
\hline \multirow{2}{*}{ No } & \multicolumn{1}{|c|}{ Komponen Biaya } & Satuan & Volume & Harga Satuan (Rp) & \multirow{2}{*}{ Usia pakai (Tahun) } \\
\hline \hline 1 & Rumah jaga dan gudang & Unit & 1 & 5.000 .000 & 5 \\
\hline 2 & Kandang sapi & Unit & 1 & 8.000 .000 & 5 \\
\hline 3 & Pagar & Paket & 1 & 3.000 .000 & 5 \\
\hline 4 & Sumur bor & Buah & 1 & 12.000 .000 & 5 \\
\hline 5 & Pompa air & Buah & 1 & 1.500 .000 & 2 \\
\hline 6 & Bak air & Buah & 1 & 3.000 .000 & 5 \\
\hline 7 & Instalasi air & Paket & 1 & 1.000 .000 & 5 \\
\hline 9 & Instalasi listrik & Peralatan perkebunan & 1 & 2.000 .000 & 5 \\
\hline 10 & $\begin{array}{l}\text { Mesin Pencacah hijauan } \\
\text { pakan }\end{array}$ & Unit & 2 & 1.500 .000 & $\mathbf{4 4 . 5 0 0 . 0 0 0}$ \\
\hline
\end{tabular}

Hasil analisis pada data Tabel 2. Menunjukkan bahwa komponen biaya atau investasi memiliki nilai sebanyak Rp. 44.500.000.- Dengan komponen biaya terbesar pada pembuatan sumur bor Rp. 12.000.000.- Kemudian untuk biaya kandang sapi memiliki komponen biaya sebesar Rp. 8.000.000.- Komponen biaya operasional sistem pertanian terpadu jagung manis dan penggemukan sapi disajikan pada Tabel 3. 
Tabel 3. Biaya operasional pertanian terpadu jagung manis dan penggemukan sapi

\begin{tabular}{|c|c|c|c|c|c|}
\hline No. & Komponen Biaya & Volume & Satuan & $\begin{array}{c}\text { Harga satuan } \\
\text { (Rp) }\end{array}$ & $\begin{array}{l}\text { Total Nilai } \\
\text { (Rp/unit) }\end{array}$ \\
\hline $\mathbf{A}$ & \multicolumn{4}{|l|}{ Operasional Kerja } & \\
\hline 1 & Sapi bakalan & 30 & Ekor & 6.000 .000 & 180.000 .000 \\
\hline 2 & Obat-obatan & 3 & Paket & 400.000 & 1.200 .000 \\
\hline 3 & Listrik & 36 & Bulan & 100.000 & 3.600 .000 \\
\hline 4 & BBM & 630 & Liter & 10.000 & 6.300 .000 \\
\hline 5 & $\begin{array}{l}\text { Konsentrat }(7,5 \mathrm{~kg} / \text { ekor/hari) } \\
\text { (Rp.450.000/50 kg) }\end{array}$ & 24570 & $\mathrm{Kg}$ & 3.000 & 73.710 .000 \\
\hline 6 & Biaya pemasaran sapi $(300.000 / 3$ ekor $)$ & 30 & Ekor & 100.000 & 3.000 .000 \\
\hline 7 & Benih (untuk 1 ha, 4 kali/tahun) & 32 & $\mathrm{Kg}$ & 480.000 & 15.360 .000 \\
\hline 8 & Pengolahan tanah & 4 & Paket & 1.500 .000 & 6.000 .000 \\
\hline 9 & Penanaman & 4 & Paket & 1.500 .000 & 6.000 .000 \\
\hline 10 & $\begin{array}{l}\text { Pemupukan (umur } 14 \text { dan } 30 \text { hari, } 10 \\
\text { orang) }\end{array}$ & 80 & $\mathrm{OK}$ & 100.000 & 8.000 .000 \\
\hline 11 & Pestisida nabati & 4 & Paket & 250.000 & 1.000 .000 \\
\hline \multirow[t]{2}{*}{12} & Pemasaran jagung & 152 & Kali & 25.000 & 3.800 .000 \\
\hline & Jumlah & & & & 307.970 .000 \\
\hline
\end{tabular}

Hasil analisis data pada Tabel 3. Menunjukkan bahwa untuk biaya operasional pertanian terpadu jagung manis dan penggemukan sapi sebanyak Rp. 307.970.000. Dengan melihat asumsi pembelian sapi bakalan sebanyak 30 ekor dengan harga/ekor Rp. 6000.000. Sehingga total keseluruhan sebanyak Rp. 180.000.000. Sedangkan untuk Konsentrat (7,5 kg/ekor/hari) (Rp.450.000/50 kg) dengan nilai secara keseluruhan berjumlah Rp. 73.710.000. Proyeksi laba-rugi sistem pertanian terpadu jagung manis dan penggemukan sapi disajikan pada Tabel 4.

Tabel 4. Proyeksi laba-rugi pertanian terpadu jagung manis dan penggemukan sapi

\begin{tabular}{|c|c|c|c|c|c|c|}
\hline \multirow{2}{*}{ No } & \multirow{2}{*}{ Uraian } & \multicolumn{5}{|c|}{ Tahun } \\
\hline & & 1 & 2 & 3 & 4 & 5 \\
\hline \multirow[t]{2}{*}{$\mathrm{A}$} & Penerimaan & & & & & \\
\hline & Total Penerimaan & 464.000 .000 & 544.000 .000 & 544.000 .000 & 544.000 .000 & 544.000 .000 \\
\hline \multirow[t]{7}{*}{$\mathrm{B}$} & Pengeluaran & & & & & \\
\hline & i. Biaya Variabel & 214.100 .000 & 301.170 .000 & 301.170 .000 & 301.170 .000 & 301.170 .000 \\
\hline & & & & & & \\
\hline & ii. Biaya Tetap & 7.400 .000 & 7.400 .000 & 7.400 .000 & 7.400 .000 & 7.400 .000 \\
\hline & iii. Angsuran Bunga & 113.461 .323 & 32.040 .573 & 22.993 .823 & 13.947 .073 & 4.900 .323 \\
\hline & $\begin{array}{l}\text { iv. Biaya } \\
\text { Pemasaran/Distribusi }\end{array}$ & 5.800 .000 & 6.800 .000 & 6.800 .000 & 6.800 .000 & 6.800 .000 \\
\hline & Total Pengeluaran & 340.761 .323 & 347.410 .573 & 338.363 .823 & 329.317 .073 & 320.270 .323 \\
\hline $\mathrm{C}$ & Laba Sebelum Pajak & 123.238 .677 & 196.589 .427 & 205.636 .177 & 214.682 .927 & 223.729 .677 \\
\hline $\mathrm{D}$ & Pajak (15\%) & 69.600 .000 & 81.600 .000 & 81.600 .000 & 81.600 .000 & 81.600 .000 \\
\hline $\mathrm{E}$ & Laba Setelah Pajak & 53.638 .677 & 114.989 .427 & 124.036 .177 & 133.082 .927 & 142.129 .677 \\
\hline $\mathrm{F}$ & Profit on Sales & $26,56 \%$ & $36,14 \%$ & $37,80 \%$ & $39,46 \%$ & $41,13 \%$ \\
\hline $\mathrm{G}$ & BEP : Rupiah & 8.141 .243 & 16.577 .853 & 16.577 .853 & 16.577 .853 & 16.577 .853 \\
\hline $\mathrm{H}$ & BEP : ekor setara sapi & 1,02 & 1,12 & 1,12 & 1,12 & 1,12 \\
\hline
\end{tabular}

Hasil analisis pada Tabel 4. Menunjukkan bahwa total penerimaan pada tahun ke-5 berjumlah Rp. 544.000.000 sedangkan untuk pengeluaran berjumlah Rp. 320.270.323 dengan BEP Rp. 16.577.853 atau setara sapi 1,12. Proyeksi arus kas dan analisis kelayakan usaha pertanian terpadu jagung manis dan penggemukan sapi disajikan pada Tabel 5. 
Tabel 5. Proyeksi arus kas dan analisis kelayakan usaha pertanian terpadu

\begin{tabular}{|c|c|c|c|c|c|c|c|}
\hline \multirow{2}{*}{ No } & \multirow{2}{*}{ Uraian } & \multicolumn{2}{|c|}{ Tahun } & \multirow[b]{2}{*}{2} & \multirow[b]{2}{*}{3} & \multirow[b]{2}{*}{4} & \multirow[b]{2}{*}{5} \\
\hline & & $\mathbf{0}$ & 1 & & & & \\
\hline \multirow[t]{11}{*}{$\mathbf{A}$} & Arus Masuk & & & & & & \\
\hline & 1. Total Penjualan & - & 464.000 .000 & 544.000 .000 & 544.000 .000 & 544.000 .000 & 544000000 \\
\hline & 2. Kredit & & & & & & \\
\hline & a. Investasi & 46.500 .000 & & & & & \\
\hline & b. Modal Operasional & & 315.370 .000 & & & & \\
\hline & 3. Sendiri & & & & & & \\
\hline & a. Investasi & - & & & & & \\
\hline & b. Modal Operasional & & - & & & & \\
\hline & 4. Nilai Sisa Proyek & & & & & & 9.300 .000 \\
\hline & Total Arus Masuk & 46.500 .000 & 779.370 .000 & 544.000 .000 & 544.000 .000 & 544.000 .000 & 553.300 .000 \\
\hline & Arus Masuk untuk IRR & - & 464.000 .000 & 544.000 .000 & 544.000 .000 & 544.000 .000 & 1.097 .300 .000 \\
\hline \multirow[t]{10}{*}{ B } & Arus Keluar & & & & & & \\
\hline & 1. Biaya Investasi & 46.500 .000 & - & - & - & - & - \\
\hline & 2. Biaya Variabel & & 214.100 .000 & 301.170 .000 & 301.170 .000 & 301.170 .000 & 301.170 .000 \\
\hline & 3. Biaya Tetap & & 7.400 .000 & 7.400 .000 & 7.400 .000 & 7.400 .000 & 7.400 .000 \\
\hline & 4. Angsuran Pokok & & 72.374 .000 & 72.374 .000 & 72.374 .000 & 72.374 .000 & 72.374 .000 \\
\hline & 5. Angsuran Bunga & & 41.087 .323 & 32.040 .573 & 22.993 .823 & 13.947 .073 & 4.900 .323 \\
\hline & 6. Pajak $(15 \%)$ & & 69.600 .000 & 81.600 .000 & 81.600 .000 & 81.600 .000 & 81.600 .000 \\
\hline & 7. Biaya Pemasaran & & 5.800 .000 & 6.800 .000 & 6.800 .000 & 6.800 .000 & 6.800 .000 \\
\hline & Total Arus Keluar & 46.500 .000 & 410.361 .323 & 501.384 .573 & 492.337 .823 & 483.291 .073 & 474.244 .323 \\
\hline & Arus Keluar untuk IRR & 46.500 .000 & 296.900 .000 & 396.970 .000 & 396.970 .000 & 396.970 .000 & 396.970 .000 \\
\hline $\mathbf{C}$ & Arus Bersih (NCF) & - & 369.008 .677 & 42.615 .427 & 51.662 .177 & 60.708 .927 & 79.055 .677 \\
\hline D & Cashflow untuk IRR & $(46.500 .000)$ & 167.100 .000 & 147.030 .000 & 147.030 .000 & 147.030 .000 & 700.330 .000 \\
\hline E & Suku Bunga 12.5\% & 1,00 & 0,89 & 0,79 & 0,70 & 0,62 & 0,55 \\
\hline $\mathbf{F}$ & PRESENT VALUE & $(46.500 .000)$ & 148.533 .333 & 116.171 .852 & 103.263 .868 & 91.790 .105 & 388.633 .397 \\
\hline G & CUMMULATIVE PV & $(46.500 .000)$ & 102.033 .333 & 218.205 .185 & 321.469 .053 & 413.259.159 & 801.892 .555 \\
\hline \multirow[t]{5}{*}{$\mathbf{H}$} & $\begin{array}{l}\text { ANALISIS KELAYAKAN } \\
\text { USAHA }\end{array}$ & Per Tahun & \multicolumn{5}{|l|}{ Keterangan } \\
\hline & NPV (Rp/thn) & 464.722 .921 & \multicolumn{5}{|c|}{ Layak diusahakan karena memiliki NPV Positif } \\
\hline & IRR (\%) & $302 \%$ & \multicolumn{5}{|c|}{$\begin{array}{l}\text { Layak diusahakan karena memiliki IRR yang lebih besar dari tingkat suku bunga } \\
\text { berlaku }(12,5 \%)\end{array}$} \\
\hline & BCR & 1,76 & \multicolumn{5}{|c|}{ Layak diusahakan karena memiliki BCR yang lebih besar dari satu } \\
\hline & PBP & 2,7 & \multicolumn{5}{|c|}{$\begin{array}{l}\text { Layak diusahakan karena memiliki Pay Back Period (PBP) yang lebih cepat dari } \\
\text { jangka waktu analisis ( } 5 \text { tahun) }\end{array}$} \\
\hline
\end{tabular}

\subsection{Hasil Analisis Monokultur Jagung Manis}

Berbagai permasalahan dalam agroindustri sapi potong-jagung harus segera diatasi guna meningkatkan produksi dalam negeri terutama peningkatan produksi sapi potong, jagung dan pemanfaatan limbah sapi potong-jagung (Suprihatin \& Sukardi, 2018). Langkah pengembangan pada agroindustri terpadu sapi potong-jagung berkelanjutan dibangun berdasarkan beberapa bagian yaitu bahan baku (sapi potongjagung), teknologi penggemukan sapi potong/penanaman jagung, biaya penggemukan/penanaman, dan pemanfaatan limbah sapi potong jagung. Asumsi pada sistem pertanian monokultur jagung manis disajikan pada Tabel 6.

Tabel 6. Asumsi sistem pertanian monokultur jagung manis

\begin{tabular}{|c|l|l|l|}
\hline No & \multicolumn{1}{|c|}{ Asumsi } & \multicolumn{1}{|c|}{ Satuan } & \multicolumn{1}{|c|}{$\begin{array}{c}\text { Nilai / } \\
\text { Jumlah }\end{array}$} \\
\hline 1 & Periode proyek & Tahun & 5 \\
\hline 2 & Benih jagung manis (rp. 480.000 per kg) & $\mathrm{Kg} / \mathrm{Ha}$ & 8 \\
\hline 3 & Biaya pengolahan tanah & $\mathrm{Rp} / \mathrm{Ha}$ & 1.500 .000 \\
\hline 4 & Biaya penanaman & $\mathrm{Rp} / \mathrm{Ha}$ & 1.500 .000 \\
\hline 5 & Biaya pemupukan (pada umur tanam 14 hari dan 30 hari) & $\mathrm{Rp} / \mathrm{Ha}$ & 1.000 .000 \\
\hline 6 & Populasi jagung layak panen & $\mathrm{Tkl} / \mathrm{Ha}$ & 38.000 \\
\hline 7 & Harga jual per tongkol & Rp/Tkl & 2.000 \\
\hline 8 & Umur panen & Hari & 70 \\
\hline
\end{tabular}




\begin{tabular}{|c|l|l|l|}
\hline No & \multicolumn{1}{|c|}{ Asumsi } & \multicolumn{1}{c|}{ Satuan } & \multicolumn{1}{c|}{$\begin{array}{c}\text { Nilai / } \\
\text { Jumlah }\end{array}$} \\
\hline 9 & Jumlah kali panen & Kali/Thn & 4 \\
\hline 10 & Tenaga kerja keluarga & Orang & 5 \\
\hline
\end{tabular}

Hasil asumsi pada Tabel 6. Menunjukkan bahwa untuk biaya pengolahan tanah berjumlah Rp. 1.500.000 dan Biaya penanaman Rp. 1.500.000. Sementara itu, untuk biaya pemupukan (pada umur tanam 14 hari dan 30 hari) berjumlah Rp. 1.000.000. Komponen investasi pada sistem pertanian monokultur jagung manis disajikan pada Tabel 2.

Tabel 7. Komponen investasi sistem pertanian monokultur jagung manis

\begin{tabular}{|c|l|l|c|c|c|}
\hline No & \multicolumn{1}{|c|}{ Komponen Biaya } & Satuan & Volume & $\begin{array}{c}\text { Harga Satuan } \\
\text { (Rp) }\end{array}$ & $\begin{array}{c}\text { Usia pakai } \\
\text { (Tahun) }\end{array}$ \\
\hline \hline 1 & Rumah jaga dan gudang & Unit & 1 & 5.000 .000 & 5 \\
\hline 2 & Pagar & Paket & 1 & 3.000 .000 & 5 \\
\hline 3 & Sumur bor & Buah & 1 & 12.000 .000 & 20 \\
\hline 4 & Pompa air & Buah & 1 & 1.500 .000 & 5 \\
\hline 5 & Bak air & Buah & 1 & 3.000 .000 & 5 \\
\hline 6 & Instalasi air & Paket & 1 & 1.000 .000 & 2 \\
\hline 7 & Instalasi listrik & Paket & 1 & 6.000 .000 & 5 \\
\hline 8 & Peralatan perkebunan & Paket & 1 & 2.000 .000 & 5 \\
\hline Jumlah & & & $\mathbf{3 3 . 5 0 0 . 0 0 0}$ & \\
\hline
\end{tabular}

Komponen investasi sistem pertanian monokultur jagung manis sebanyak Rp. 33.500.000, dengan komponen investasi terbanyak terdapat pada Sumur bor dengan nilai investasi sebanyak 12.000.000 dengan usia pakai selama 20 tahun. Kemudian instalasi listrik dengan nilai investasi Rp. 6.000.000 dengan usia pakai selama 5 tahun. Komponen biaya operasional pada sistem pertanian monokultur jagung manis disajikan pada Tabel 8.

Tabel 8. Komponen biaya operasional sistem pertanian monokultur jagung manis

\begin{tabular}{|c|l|c|c|l|l|}
\hline No. & \multicolumn{1}{|c|}{ Komponen Biaya } & Volume & Satuan & Harga satuan (Rp) & $\begin{array}{c}\text { Total Nilai } \\
\text { (Rp/unit) }\end{array}$ \\
\hline \hline A & Operasional Kerja & 36 & Bulan & 100.000 & \\
\hline 1 & Listrik & 4 & Paket & 1.500 .000 & 3.600 .000 \\
\hline 2 & Pengolahan tanah & 4 & Paket & 1.500 .000 & 6.000 .000 \\
\hline 3 & Penanaman & 120 & OK & 100.000 & 12.000000 \\
\hline 4 & Pemupukan (awal, umur 14 dan 30 hari, 10 orang) & 32 & Kg & 480.000 & 15.360 .000 \\
\hline 5 & Benih (untuk 1 ha, 4 kali/tahun) & 1200 & Kg & 15.000 & 18.000 .000 \\
\hline 6 & Pupuk Urea (300 kg x 4) & 2000 & Kg & 10.000 & 20.000 .000 \\
\hline 7 & Pupuk petroganik (500 kg X 4) & 1200 & Kg & 20.000 & 24.000 .000 \\
\hline 8 & Pupuk NPK Ponska (300 kg x 4) & 40 & Kg & 30.000 & 1.200 .000 \\
\hline 9 & Petrofur (10 kg x 4) & 152 & Kali & 25.000 & 3.800 .000 \\
\hline 10 & Pemasaran jagung & & & $\mathbf{1 0 9 . 9 6 0 . 0 0 0}$ \\
\hline Jumlah Biaya Operasional Kerja
\end{tabular}

Komponen biaya operasional terbanyak pada sistem pertanian monokultur jagung manis terdapat pada Pupuk petroganik (500 kg X 4) sebanyak Rp. 20.000.000 dan Pupuk NPK Ponska (300 kg x 4) sebanyak Rp. 24.000.000. Proyeksi laba/rugi pada sistem pertanian monokultur jagung manis disajikan pada Tabel 9.

Tabel 9. Proyeksi laba/rugi pada sistem pertanian monokultur jagung manis 


\begin{tabular}{|c|c|c|c|c|c|c|}
\hline \multirow{2}{*}{ No } & \multirow{2}{*}{ Uraian } & \multicolumn{5}{|c|}{ Tahun } \\
\hline & & 1 & 2 & 3 & 4 & 5 \\
\hline \multirow[t]{2}{*}{$\mathrm{A}$} & Penerimaan & & & & & \\
\hline & Total Penerimaan & 304.000 .000 & 304.000 .000 & 304.000 .000 & 304.000 .000 & 304.000 .000 \\
\hline \multirow[t]{6}{*}{$\mathrm{B}$} & Pengeluaran & & & & & \\
\hline & i. Biaya Variabel & 109.960 .000 & 109.960 .000 & 109.960 .000 & 109.960 .000 & 109.960 .000 \\
\hline & ii. Biaya Tetap & 5.200 .000 & 5.200 .000 & 5.200 .000 & 5.200 .000 & 5.200 .000 \\
\hline & iii. Angsuran Bunga & 47.238 .188 & 13.339 .688 & 9.573 .188 & 5.806 .688 & 2.040 .188 \\
\hline & iv. Biaya Pemasaran/Distribusi & 3.800 .000 & 3.800 .000 & 3.800 .000 & 3.800 .000 & 3.800 .000 \\
\hline & Total Pengeluaran & 166.198.188 & 132.299 .688 & 128.533.188 & 124.766 .688 & 121.000 .188 \\
\hline $\mathrm{C}$ & Laba Sebelum Pajak & 137.801 .813 & 171.700 .313 & 175.466 .813 & 179.233 .313 & 182.999 .813 \\
\hline $\mathrm{D}$ & Pajak (15\%) & 45.600 .000 & 45.600 .000 & 45.600 .000 & 45.600 .000 & 45.600 .000 \\
\hline E & Laba Setelah Pajak & 92.201 .813 & 126.100 .313 & 129.866 .813 & 133.633 .313 & 137.399 .813 \\
\hline $\mathrm{F}$ & Profit on Sales & $45,33 \%$ & $56,48 \%$ & $57,72 \%$ & $58,96 \%$ & $60,20 \%$ \\
\hline $\mathrm{G}$ & BEP : Rupiah & 1.762 .319 & 8.146 .774 & 8.146 .774 & 8.146 .774 & 8.146 .774 \\
\hline $\mathrm{H}$ & BEP : Tongkol & 881 & 881 & 881 & 881 & 881 \\
\hline
\end{tabular}

Hasil analisis proyeksi laba/rugi pada Tabel 9. Menunjukkan bahwa untuk penerimaan pada tahun kelima penerimaan pada sistem pertanian monokultur jagung manis berjumlah Rp. 304.000.000 dan pengeluaran 121.000.188 serta laba Sebelum Pajak sebesar Rp. 182.999.813. Proyeksi arus kas dan analisis kelayakan usaha pada sistem pertanian monokultur jagung manis disajikan pada Tabel 10.

Tabel 10. Proyeksi arus kas analisis kelayakan usaha pertanian monokultur jagung manis

\begin{tabular}{|c|c|c|c|c|c|c|c|}
\hline \multirow{2}{*}{ No } & \multirow{2}{*}{ Uraian } & \multicolumn{6}{|c|}{ Tahun } \\
\hline & & $\mathbf{0}$ & 1 & 2 & 3 & 4 & 5 \\
\hline \multirow[t]{11}{*}{ A } & Arus Masuk & & & & & & \\
\hline & 1. Total Penjualan & - & 304.000 .000 & 304.000 .000 & 304.000 .000 & 304.000 .000 & 304000000 \\
\hline & 2. Kredit & & & & & & \\
\hline & a. Investasi & 35.500 .000 & & & & & \\
\hline & b. Modal Operasional & & 115.160 .000 & & & & \\
\hline & 3. Sendiri & & & & & & \\
\hline & a. Investasi & - & & & & & \\
\hline & b. Modal Operasional & & - & & & & \\
\hline & 4. Nilai Sisa Proyek & & & & & & 7.800 .000 \\
\hline & Total Arus Masuk & 35.500 .000 & 419.160 .000 & 304.000 .000 & 304.000 .000 & 304.000 .000 & 311.800 .000 \\
\hline & Arus Masuk untuk IRR & - & 304.000 .000 & 304.000 .000 & 304.000 .000 & 304.000 .000 & 615.800 .000 \\
\hline \multirow[t]{10}{*}{ B } & Arus Keluar & & & & & & \\
\hline & 1. Biaya Investasi & 35.500 .000 & - & - & - & - & - \\
\hline & 2. Biaya Variabel & & 109.960 .000 & 109.960 .000 & 109.960 .000 & 109.960 .000 & 109.960 .000 \\
\hline & 3. Biaya Tetap & & 5.200 .000 & 5.200 .000 & 5.200 .000 & 5.200 .000 & 5.200 .000 \\
\hline & 4. Angsuran Pokok & & 30.132 .000 & 30.132 .000 & 30.132 .000 & 30.132 .000 & 30.132 .000 \\
\hline & 5. Angsuran Bunga & & 17.106.188 & 13.339 .688 & 9.573 .188 & 5.806 .688 & 2.040 .188 \\
\hline & 6. Pajak (15\%) & & 45.600 .000 & 45.600 .000 & 45.600 .000 & 45.600 .000 & 45.600 .000 \\
\hline & 7. Biaya Pemasaran & & 3.800 .000 & 3.800 .000 & 3.800 .000 & 3.800 .000 & 3.800 .000 \\
\hline & Total Arus Keluar & 35.500 .000 & 211.798 .188 & 208.031 .688 & 204.265 .188 & 200.498 .688 & 196.732 .188 \\
\hline & Arus Keluar untuk IRR & 35.500 .000 & 164.560 .000 & 164.560 .000 & 164.560 .000 & 164.560 .000 & 164.560 .000 \\
\hline C & Arus Bersih (NCF) & - & 207.361.813 & 95.968 .313 & 99.734 .813 & 103.501 .313 & 115.067 .813 \\
\hline D & Cashflow untuk IRR & $(35.500 .000)$ & 139.440 .000 & 139.440 .000 & 139.440 .000 & 139.440 .000 & 451.240 .000 \\
\hline E & Suku Bunga 12.5\% & 1,00 & 0,89 & 0,79 & 0,70 & 0,62 & 0,55 \\
\hline $\mathbf{F}$ & PRESENT VALUE & $(35.500 .000)$ & 123.946 .667 & 110.174 .815 & 97.933 .169 & 87.051 .706 & 250.406 .143 \\
\hline G & CUMMULATIVE PV & $(35.500 .000)$ & 88.446 .667 & 198.621 .481 & 296.554 .650 & 383.606 .356 & 634.012 .498 \\
\hline \multirow[t]{5}{*}{$\mathbf{H}$} & $\begin{array}{l}\text { ANALISIS KELAYAKAN } \\
\text { USAHA }\end{array}$ & Per Tahun & \multicolumn{5}{|c|}{ Keterangan } \\
\hline & NPV (Rp/thn) & 376.721 .498 & \multicolumn{5}{|c|}{ Layak diusahakan karena memiliki NPV Positif } \\
\hline & IRR $(\%)$ & $339 \%$ & \multicolumn{5}{|c|}{$\begin{array}{l}\text { Layak diusahakan karena memiliki IRR yang lebih besar dari tingkat suku bunga } \\
\text { berlaku }(12,5 \%)\end{array}$} \\
\hline & BCR & 2,74 & \multicolumn{5}{|c|}{ Layak diusahakan karena memiliki BCR yang lebih besar dari satu } \\
\hline & PBP & 2,6 & \multicolumn{5}{|c|}{$\begin{array}{l}\text { Layak diusahakan karena memiliki Pay Back Period (PBP) yang lebih cepat dari } \\
\text { jangka waktu analisis ( } 5 \text { tahun) }\end{array}$} \\
\hline
\end{tabular}




\subsection{Potensi Pengembangan Integrasi Ternak dan Jagung Manis}

Sapi potong merupakan salah satu sumber daya penghasil bahan makanan berupa daging yang memiliki nilai ekonomis yang tinggi, dan penting artinya di dalam kehidupan masyarakat (Suprihatin \& Sukardi, 2018). Lahan sempit merupakan kendala utama dalam upaya peningkatan pendapatan petani sehingga lahan tersebut harus dimanfaatkan secara maksimal. Menurut Suwarto \& Prihantoro, (2020) melaporkan bahwa Jagung dipanen dalam bentuk tongkol kering berkelobot, selanjutnya dirontokkan dengan thresher dan menghasilkan sebanyak 70\% biji pipilan kering, sisanya sebanyak 30\% berupa limbah tongkol dan kelobot. Rata-rata bobot tongkol berkelobot adalah sebanyak 9,29 ton ha yang menghasilkan biji sebanyak 6,50 ton ha dan brangkasan berupa tongkol dan kelobot sebanyak 2,79 ton/ha. Brangkasan ini juga belum dimanfaatkan, masih dibiarkan berserakan di lahan dan/atau sekitar rumah. Sedangkan menurut Marjaya, (2016) melaporkan bahwa Sistem usahatani integrasi jagung-sapi sangat menentukan keberhasilan produk yang bisa bersaing dipasar, sekaligus membuka peluang kesempatan kerja dan memberikan pendapatan bagi petani sekaligus mempengaruhi produksi, pendapatan, efisiensi dan daya saing sistem usahatani integrasi jagung-sapi di Kabupaten Kupang. Sedangkan penelitian yang dilakukan oleh Baba et al., (2014) melaporkan bahwa Faktor yang paling menghambat adopsi pemanfaatan limbah jerami sebagai pakan ternak di kabupaten Maros adalah tidak adanya tempat penampungan pakan, ketidaktahuan petani dalam mengolah jerami dan masih banyaknya alternatif pakan yang lain. Sekaligus pemanfaatan limbah feces sebagai pupuk organik tidak diketahui oleh petani dan masih membutuhkan biaya untuk membuat pupuk organik.

Pemanfaatan jerami jagung sebagai pakan ternak sebenarnya masih banyak memiliki kendala dalam pemanfaatannya. Beberapa faktor pembatas sehubungan dengan penggunaan limbah pertanian sebagai pakan meliputi penyimpanan, konsumsi pakan kandungan nutrien yang rendah seperti limbah jagung (Seran et al., 2020). Selanjutnya penampilan ternak yang rendah (Badarina et al., 2015). Tongkol jagung mengandung lignoselulosa yang terdiri dari lignin, selulosa, dan hemiselulosa (Hatta \& Sugiarto, 2015). Tongkol jagung dapat dimanfaatkan sebagai pakan alternatif karena mudah didapat, kandungan nutrisinya memadai dan ketersediaannya cukup. Sehingga berpotensi untuk dijadikan sebagai pakan ternak (Prastyawan et al., 2012). Kandungan nutrisi tongkol jagung terdiri dari bahan kering 90,0\%, bahan organik 88,5\%, protein kasar 2,8\%, lemak kasar 0,7\%, abu 1,5\%, serat kasar 32,7\%, dinding sel 80\%, lignin 6,0\%, dan ADF 32\% (Islamiyati et al., 2013; Ruhibnur et al., 2019; Hindratiningrum \& Primandini, 2020).

Konsumsi dan kecernaan nutrisi terutama kandungan protein kasar, serat kasar dan lemak kasar sangat mempengaruhi produktivitas ternak karena diperlukan kecukupan nutrisi untuk meningkatkan aktivitas mikroorganisme rumen dari ternak ruminansia. Penelitian yang dilakukan oleh Klau et al., (2020) melaporkan bahwa substitusi jagung giling sebanyak $66,67 \%$ oleh tepung tongkol jagung hasil fermentasi khamir Saccharomyces cerevisiae dari proporsi jagung giling 30\% dalam campuran pakan konsentrat dapat meningkatkan kandungan protein kasar dan menurunkan kandungan lemak kasar dari campuran konsentrat berbasis jagung giling. Begitupun penelitian yang dilakukan oleh Khasanah et al., (2019) mengungkapkan bahwa kandungan serat kasar pakan fermentasi dari yang terendah yaitu P2 (17,52\%), P4 $(18,30 \%)$, P0 $(18,70 \%)$, P1 (20,05\%) dan P3 (20,65\%). Secara umum protein kasar pakan fermentasi masih rendah. Aplikasi MOL sebagai substitusi biostarter komersil EM4 tongkol dan tumpi jagung dapat dimanfaatkan sebagai pakan ternak dengan 
aplikasi teknologi pengolahan pakan fermentasi dan penambahan bahan yang berprotein tinggi. Penelitian sebelumnya yang dilakukan oleh Gustiani \& Permadi, (2015) mengungkapkan bahwa 1) fermentasi pada tongkol jagung meningkatkan kandungan protein kasar dari 1,92 menjadi 2,4\%; 2) kandungan protein kasar pakan lengkap 11,76\%; dan 3) pemberian pakan lengkap pada sapi P0 di Kelompok Lengo menunjukkan rataan pertambahan berat badan harian $(\mathrm{PBBH})$ yang lebih tinggi $(0,4-$ $0,82 \mathrm{~kg} /$ ekor/hari) dibandingkan dengan perlakuan pada kelompok A/kontrol $(0,10-$ $0,39 \mathrm{~kg} /$ ekor/hari).

\subsection{Pendapatan Petani terhadap sistem Integrasi Ternak-Tanaman Pangan}

Pengembangan usaha ternak sapi potong merupakan bagian yang tak terpisahkan dari semua jenis pengembangan usaha sektor pertanian yang biasa dilaksanakan oleh masyarakat di wilayah pedesaan. Penelitian yang dilakukan oleh Zakiatulyaqin et al., (2017) melaporkan bahwa penggemukan ternak sapi dengan pakan berbasis limbah sawit dengan berbagai konsentrasi protein kasar 14\%, 16\% dan 18\% menghasilkan evaluasi usaha peternakan sapi yang sama tidak berbeda nyata dan berdasarkan perhitungan Income Over Feed Cost (IOFC) dan R-C ratio. Upaya yang dapat dilakukan guna meningkatkan produksi tanaman jagung sebagai pakan ternak adalah dengan memperhatikan jarak tanam dan penggunaan varietas yang ditanam (Farda et al., 2020). Hal ini juga sesuai dengan penelitian yang dilakukan oleh (Muh Jurhadi Kadir, 2020) melaporkan bahwa perkembangan struktur ekonomi petani yang menerapkan usahatani monokultur memberi kontribusi pendapatan sebesar Rp 9.213.550,00 dengan B/C Ratio 1,38 dan petani yang menerapkan usahatani sapi monokultur diperoleh pendapatan sebesar Rp 6.856.166,66 dengan B/C Ratio 0,89, sedangkan usahatani padisapi terpadu diperoleh pendapatan sebesar Rp 17.981.726,95 dengan B/C Ratio 1,73. Begitupun penelitian yang dilakukan oleh Kurniati et al., (2019) melaporkan bahwa pendapatan usahatani integrasi sebesar Rp 72.209.416,69 / tahun, dengan kontribusi usahatani padi sebesar 28,38 persen, sedangkan kontribusi dari usahaternak sapi potong sebesar 71,62 persen. Hal ini didukung pula oleh penelitian yang dilakukan oleh Tarmizi \& Safaruddin, (2015) mengungkapkan bahwa Sistem Integrasi Padi Ternak (SIPT) berpengaruh terhadap pendapatan petani di Kabupaten Serdang Bedagai, di mana terdapat perbedaan yang signifikan antara pendapatan per hektar petani SIPT dengan pendapatan petani non SIPT. Perbedaan pendapatan adalah sebesar Rp. 666.923 per hektar.

Widhyawaty, (2019) melaporkan bahwa Rata-rata pendapatan petani-peternak Simantri di Desa Kerta Kecamatan Payangan Kabupaten Gianyar sebesar Rp. 39.477.041,00 pertahun lebih tinggi dari pendapatan petani-peternak non Simantri sebesar Rp. 28.299.632,70 pertahun. Sementara itu penelitian yang dilakukan oleh (Hilmiati, 2019) melaporkan bahwa Kabupaten Sumbawa memiliki potensi besar untuk perbaikan peternakan sapi dengan memanfaatkan sisa tanaman jagung (brangkasan) yang tersedia melimpah setiap tahun namun belum dimanfaatkan dengan sistem pemeliharaan yang intensif untuk penggemukan sapi dengan pendapatan signifikan kepada petani sejumlah Rp. 500.000/ekor/bulan. Hal ini juga sesuai dengan penelitian yang dilakukan oleh Ervina et al., (2019) mengungkapkan bahwa pendapatan usaha ternak sapi perah sebesar Rp 872.772.364/tahun. Variabel harga jual ternak, upah tenaga kerja, harga pakan tambahan, jumlah sapi laktasi terkoreksi jumlah produksi susu mempunyai pengaruh yang nyata terhadap pendapatan usaha ternak sapi perah.

Indrayani \& Andri, (2018) mengungkapkan bahwa pendapatan peternak dari usaha ternak sapi di Kecamatan Sitiung selama satu tahun adalah sebesar Rp. 8.579.213,- dengan rata-rata kepemilikan ternak 4,3 ekor. Sementara itu penelitian yang 
dilakukan oleh Kusumayana \& Arlina, (2017) melaporkan bahwa Total biaya pada sistem integrasi tanaman pangan ternak sapi di Desa Jaro Kecamatan Jaro Kabupaten Tabalong yaitu sebesar Rp. 37.527.195-/tahun dengan total penerimaan pada sistem integrasi tanaman pangan ternak sapi yaitu sebesar Rp. 90.025.454,-/tahun, total pendapatan pada sistem integrasi tanaman pangan ternak sapi yaitu sebesar Rp. 56.170.067,- /tahun dengan rata-rata luas lahan yang dimiliki 0,8 Ha dan kepemilikan ternak 2,6 dan produksi limbah ternak (feses) berupa pupuk organik 711,6 Kg/tahun.

\subsection{Pengembangan Integrasi Ternak dan Tanaman Pangan di Sulawesi Tenggara}

Pengembangan subsektor tanaman pangan dan ternak sapi potong walaupun tidak menjadi kajian mendasar dalam makalah ini tetapi dengan melihat potensi yang ditawarkan dari hasil ikutan tanaman pangan sebagai sumber pakan ternak memberikan gambaran bahwa hasil ikutan tanaman pangan berupa jerami padi, jagung dan jenis tanaman pangan lainnya merupakan sumberdaya yang belum termanfaatkan dengan baik. Sehingga makalah ini mencoba mengakaji sedikit tentang gambaran pengembangan peternakan apabila memanfaatkan hasil ikutan tanaman pangan sebagai sumber pakan ternak. Dengan demikian pemanfaatan hasil ikutan tanaman pangan akan optimal seiring dengan usaha petani khususnya peternak dan petani tanaman pangan di Sulawesi Tenggara secara umum.

Produk dari tanaman jagung dapat termanfaatkan untuk berbagai macam keperluan antara lain (i) batang dan daun tanaman yang masih muda dapat digunakan sebagai pakan ternak, (ii) tanaman yang telah dipanen bisa digunakan untuk pembuatan pakan dan pupuk organik. Kandungan selulosa tongkol jagung memiliki komponen serat yang cukup tinggi yang dapat dicerna sehingga dapat menyediakan energi yang cukup untuk pertumbuhan mikroba dalam rumen. Namun, karena rendahnya kandungan protein dan tingginya kadar lignin menyebabkan selulosa menjadi tidak tersedia untuk difermentasi di dalam rumen akibatnya kecernaannya menjadi rendah (Wina \& Yulistiani, 2012). Potensi tanaman jagung di Provinsi Sulawesi Tenggara disajikan pada Tabel 1.

Tabel 11. Luas Panen dan Produksi Tanaman Jagung di Sulawesi Tenggara, 2019

\begin{tabular}{lccc}
\hline Kabupaten/Kota & Luas Panen (Ha) & $\begin{array}{c}\text { Produktivitas } \\
\text { (Ton/Ha) }\end{array}$ & Produksi (Ton) \\
\hline \multicolumn{1}{c}{$(\mathbf{1})$} & $\mathbf{( 2 )}$ & $\mathbf{( 3 )}$ & $\mathbf{( 4 )}$ \\
\hline Wakatobi & 1.139 & 24.6 & 280.0 \\
Buton & 1.273 & 33.9 & 4.312 .5 \\
Buton Selatan & 1.060 .5 & 19.3 & 1.049 .1 \\
Buton Tengah & 1.661 .0 & 18.0 & 2.983 .0 \\
Konawe & 2.730 & 42.8 & 11.677 .4 \\
Kolaka & 2.834 & 45.3 & 12.828 .6 \\
Kolaka Timur & 4.331. & 37.7 & 16.328 .7 \\
Konawe Selatan & 7.149 & 42.3 & 30.267 .5 \\
Muna Barat & 6.778 .5 & 29.8 & 20.221 .2 \\
Muna & 9.787 & 24.8 & 24.238 .2 \\
Kolaka Utara & 13.848 & 60.5 & 83.828 .1 \\
Kota Bau Bau & 279.0 & 29.4 & 818.8 \\
Kota Kendari & 346.0 & 60.0 & 2.077 .6 \\
Konawe Utara & 444.8 & 45.6 & 2.028 .4 \\
Konawe Kep. & 489,4 & 37.6 & 1.841 .3 \\
Bombana & 557 & 63.9 & 3.561 .5 \\
Buton Utara & 952.0 & 22.7 & 2.156 .8 \\
\hline
\end{tabular}




\begin{tabular}{cccc}
\hline Kabupaten/Kota & Luas Panen (Ha) & $\begin{array}{c}\text { Produktivitas } \\
\text { (Ton/Ha) }\end{array}$ & Produksi (Ton) \\
\hline (1) & $(2)$ & $(3)$ & $(4)$ \\
\hline Sulawesi Tenggara & $\mathbf{5 4 . 6 3 5 . 1}$ & $\mathbf{4 0 . 5}$ & $\mathbf{2 2 1 . 4 9 8 . 5}$ \\
\hline Sumber : Sultra .
\end{tabular}

Sumber : Sultra Dalam Angka, 2019.

Potensi Sulawesi Tenggara sebagai sentra peternakan rakyat sangat berpotensi untuk di kembangkan. Hal ini terlihat dari daya tampung hasil ikutan tanaman pangan berupa jagung yang berpotensi sebagai sumber pakan ternak. Untuk lebih jelasnya daya tampung ternak berdasarkan hasil ikutan tanaman pangan berupa jagung disajikan pada Tabel 12.

Tabel 12. Daya tampung ternak sapi berdasarkan hasil ikutan tanaman jagung

\begin{tabular}{lllcl}
\hline \multicolumn{1}{c}{ Kabupaten/Kota } & $\begin{array}{c}\text { Luas Panen } \\
\text { Tanaman } \\
\text { Jagung }\end{array}$ & $\begin{array}{c}\text { Produksi Bahan } \\
\text { Kering } \\
\text { (BK/Kg/Thn) }\end{array}$ & $\begin{array}{c}\text { Konsumsi Ternak } \\
\text { (BK/Kg/Ekor/Tahun) }\end{array}$ & $\begin{array}{c}\text { Daya } \\
\text { Tampung }\end{array}$ \\
\hline Wakatobi & 1.139 & $5,125,500$ & 2738 & $1,871.99$ \\
Buton & 1.273 & $5,728,500$ & 2738 & $2,092.22$ \\
Buton Selatan & 1.060 .5 & $4,770,000$ & 2738 & $1,742.15$ \\
Buton Tengah & 1.661 .0 & $7,474,500$ & 2738 & $2,729.91$ \\
Konawe & 2.730 & $12,285,000$ & 2738 & $4,486.85$ \\
Kolaka & 2.834 & $12,753,000$ & 2738 & $4,657.78$ \\
Kolaka Timur & 4.331 & $19,489,500$ & 2738 & $7,118.15$ \\
Konawe Selatan & 7.149 & $32,170,500$ & 2738 & $11,749.63$ \\
Muna Barat & 6.778 .5 & $30,501,000$ & 2738 & $11,139.88$ \\
Muna & 9.787 & $44,041,500$ & 2738 & $16,085.28$ \\
Kolaka Utara & 13.848 & $62,316,000$ & 2738 & $22,759.68$ \\
Kota Bau Bau & 279.0 & $1,255,500$ & 2738 & 458.55 \\
Kota Kendari & 346.0 & $1,557,000$ & 2738 & 568.66 \\
Konawe Utara & 444.8 & $1,998,000$ & 2738 & 729.73 \\
Konawe Kep. & 489.4 & $2,200,500$ & 2738 & 803.69 \\
Bombana & 557 & $2,506,500$ & 2738 & 915.45 \\
Buton Utara & 952.0 & $4,284,000$ & 2738 & $1,564.65$ \\
\hline Total Daya Tampung & $\mathbf{5 4 . 6 3 5 . 1}$ & $\mathbf{2 5 0 , 4 5 6 , 5 0 0}$ & & $\mathbf{9 1 . 4 7 4}$ \\
\hline
\end{tabular}

Hasil analisis daya tampung ternak berdasarkan hasil ikutan tanaman pangan memperlihatkan bahwa potensi pengembangan ternak sapi potong di Sulawesi Tenggara memberikan prospek pengembangan yang cukup baik. Hal ini di pengaruhi oleh luas panen tanaman pangan berupa jagung seluas 54.635.1 ha dan dapat menampung kebutuhan pakan ternak sapi potong khususnya sapi bali sebanyak 91.474 ekor. Arah pengembangan peternakan pada dasarnya dipengaruhi oleh kebutuhan pakan. Sebab pakan merupakan penghambat sekaligus memiliki peran strategis dalam pengelolaan peternakan berkelanjutan. Subsektor peternakan dan tanaman pangan di Sulawesi Tenggara merupakan langkah strategis menuju ketahanan pangan nasional. Ketahanan pangan nasional bisa dikembangkan dengan memadukan atau mengintegrasikan sektor sektor strategis baik itu pihak swasta, masyarakat serta pemangku kepentingan dalam hal pengembangan peternakan dan tanaman pangan.

Populasi ternak sapi potong di Sulawesi Tenggara pada tahun berjumlah 419.882 ekor sedangkan hasil ikutan tanaman pangan berupa jagung hanya mampu menampung kebutuhan pakan ternak sebanyak 91.474 ekor berarti terdapat 328.408 ekor ternak kekurangan pakan untuk memenuhi kebutuhan harian. Sehingga untuk memenuhi kebutuhan pakan ternak sebanyak 328.408 ekor hasil ikutan tanaman pangan berupa jerami padi merupakan salah satu alternatif untuk menanggulangi kekurangan pakan tersebut. 


\section{BAB V \\ KESIMPULAN MAKALAH}

Berdasarkan uraian pada pembahasan makalah ini dapat disimpulkan bahwa sistem pertanian terpadu mengurangi resiko kegagalan usaha karena sistem pertanian terpadu merupakan suatu sistem pertanian yang berkaitan antara komponen tanaman, lingkungan, manusi dan ternak yang terbingkai dalam suatu usaha tani. Pertanian terpadu meningkatkan efektifitas serta efisiensi produksi berupa peningkatan hasil produksi serta penurunan biaya produksi. Menganalisis produktivitas jagung manis dan penggemukan sapi potong dan menganalisis pendapatan pada usaha terpadu monokultur jagung manis dapat memberikan nilai tambah untuk pendapatan peternak dan petani tanaman pangan.

\section{DAFTAR PUSTAKA}

Asai, M., Moraine, M., Ryschawy, J., de Wit, J., Hoshide, A. K., \& Martin, G. (2018). Critical factors for crop-livestock integration beyond the farm level: A cross-analysis of worldwide case studies. Land Use Policy, 73, 184-194.

Aziz, M., Muhtarudin, \& Widodo, Y. (2014). Potensi Limbah Jerami Padi Dan Daun Singkong Untuk Mendukung Program Pembibitan Sapi Po (Peranakan Ongole) Di Desa Sidomukti Kecamatan Tanjung Sari Kabupatn Lampung Selatan. Jurnal Ilmiah Peternakan Terpadu, 2(2), 44-48.

Baba, S., Sirajuddin, S. N., Abdullah, A., \& Aminawar, M. (2014). Hambatan Adopsi Integrasi Jagung Dan Ternak Sapi Di Kabupaten Maros, Gowa Dan Takalar. JITP, 3(2), 114-120.

Badarina, I., Evvyernie, D., Toharmat, T. T., \& Herliyana, E. N. (2015). Fermentabilitas Rumen dan Kecernaan In Vitro Ransum yang Disuplementasi Kulit Buah Kopi Produk Fermentasi Jamur Pleurotus ostreatus. Jurnal Sain Peternakan Indonesia, 9(2), 102-109.

Basuni, R., \& Kusmana, C. (2015). Model Sistem Integrasi Padi-Sapi Potong Di Lahan Sawah. Forum Pascasarjana, 33(3), 177-190.

Dewi, R. K. (2019). Analisis Potensi Wilayah Pengembangan Ternak Ruminansia Di Kabupaten Lamongan. Jurnal Ternak, 9(2), 5-11.

Ervina, D., Setiadi, A., \& Ekowati, T. (2019). Analisis Faktor-Faktor Yang Mempengaruhi Pendapatan Usaha Ternak Sapi Perah Kelompok Tani Ternak Rejeki Lumintu Di Kelurahan Sumurrejo Kecamatan Gunungpati Semarang. Soca: Jurnal Sosial Ekonomi Pertanian, 13(2), 187-194.

Farda, F. T., Wijaya, A. K., Liman, L., Muhtarudin, M., Putri, D., \& Hasanah, M. (2020). Pengaruh Varietas Dan Jarak Tanam Yang Berbeda Terhadap Kandungan Nutrien Hijauan Jagung. Jurnal Ilmiah Peternakan Terpadu, 8(2), 83-90.

Fyka, S. A., Limi, M. A., Zani, M., \& Salamah, S. (2019). Analisis Potensi dan Kelayakan Usahatani Sistem Integrasi Padi Ternak (Studi Kasus di Desa Silea Jaya Kecamatan Buke Kabupaten Konawe Selatan). Jurnal Ilmu dan Teknologi Peternakan Tropis, 6(3), 375-381.

Gustiani, E., \& Permadi, K. (2015). Kajian Pengaruh Pemberian Pakan Lengkap Berbahan Baku Fermentasi Tongkol Jagung terhadap Produktivitas Ternak Sapi PO di Kabupaten Majalengka. Jurnal Peternakan Indonesia (Indonesian Journal of Animal Science), 17(1), $12-18$.

Hanifa, A., \& Sari, A. I. (2017). Penggunaan Pakan Komplit Berbasis Limbah Industri Pertanian Terhadap Produktivitas Ternak Sapi Potong di Kabupaten Boyolali. Sains Peternakan: Jurnal Penelitian Ilmu Peternakan, 13(1), 1-6.

Hatta, U., \& Sugiarto, S. (2015). Produksi tepung tongkol jagung muda hasil biodegradasi kapang Pleurotus ostreatus dengan enzim pemecah serat dan implikasinya pada pakan ayam pedaging. Jurnal Ilmu-Ilmu Peternakan, 25(3), 1-7.

Hidayati, F., Yonariza, Y., Nofialdi, N., \& Yuzaria, D. (2020). Analisis Keuntungan dan Kendala Penerapan Konsep Sistem Pertanian Terpadu (SPT) di Indonesia. JIA (Jurnal Ilmiah Agribisnis) : Jurnal Agribisnis dan Ilmu Sosial Ekonomi Pertanian, 5(3), 74-83. 
Hilmiati, N. (2019). Sistem Peternakan Sapi Di Pulau Sumbawa: Peluang Dan Hambatan Untuk Peningkatan Produktivitas Dan Pendapatan Petani Di Lahan Kering. Soca: Jurnal Sosial Ekonomi Pertanian, 142.

Hindratiningrum, N., \& Primandini, Y. (2020). Kecernaan Bahan Organik Dan Bahan Kering (In Vitro) Amofer Tongkol Jagung Dengan Penambahan Bahan Additif Yang Berbeda. Prosiding Seminar Teknologi dan Agribisnis Peternakan VII-Webinar: Prospek Peternakan di Era Normal Baru Pasca Pandemi COVID-19, Fakultas Peternakan Universitas Jenderal Soedirman, 713-719.

Indrayani, I., \& Andri, A. (2018). Faktor-faktor yang Mempengaruhi Pendapatan Usaha Ternak Sapi potong di Kecamatan Sitiung, Kabupaten Dharmasraya. Jurnal Peternakan Indonesia (Indonesian Journal of Animal Science), 20(3), 151-159.

Iskandar, E., \& Nurtilawati, H. (2019). Persepsi Petani Dan Penerapan Teknologi Pengelolaan Tanaman Terpadu Di Desa Sukaresmi Kabupaten Bogor. Jurnal Agribisnis Terpadu, 12(2), 203-216.

Islamiyati, Surahman, Y. D. A., \& Rohmiyatul. (2013). Kandungan Protein Dan Serat Kasar Tongkol Jagung Yang Diinokulasi Trichoderma sp. Pada Lama Inkubasi Yang Berbeda. Buletin Nutrisi dan makanan Ternak, 12(12), 59-63.

Kemala, N., \& Dwi Arum Sekartika. (2019). Pendapatan Pengolah Limbah Usaha Ternak Sapi Di Kecamatan Batang Asam, Kabupaten, Tanjung Jabung Barat. Jurnal MeA (Media Agribisnis), 4(1), 1-9.

Khairad, F. (2020). Analisis Wilayah Sentra Produksi Komoditas Unggulan Pada Sub Sektor Tanaman Pangan Dan Tanaman Hortikultura Di Kabupaten Agam. Agrifo: Jurnal Agribisnis Universitas Malikussaleh, 5(1), 60-72.

Khasanah, H., Purnamasari, L., \& Kusbianto, D. E. (2019). Pemanfaatan MOL (Mikroorganisme Lokal) sebagai Substitusi Biostarter EM4 untuk Meningkatkan Kualitas Nutrisi Pakan Fermentasi Berbasis Tongkol dan Tumpi Jagung. Prosiding Seminar Nasional Teknologi Peternakan dan Veteriner 2019, 345-352.

Klau, R., Enawati, L. S., \& Amalo, D. (2020). Efek substitusi jagung giling dengan tepung tongkol jagung hasil fermentasi khamir Saccharomyces cerevisiae dalam pakan konsentrat terhadap kandungan protein kasar, serat kasar dan lemak. Jurnal Peternakan Lahan Kering, 2(1), 708-716.

Kurniati, N., Efrita, E., \& Damaiyanti, D. (2019). Pendapatan Usahatani Sistem Integrasi Berbasis Padi dan Sapi di Kelurahan Rimbo Kedui Kabupaten Seluma Propinsi Bengkulu. Agrikan: Jurnal Agribisnis Perikanan, 12(1), 64-71.

Kusumayana, P., \& Arlina, A. (2017). Analisis Pendapatan Petani Melalui Sistem Integrasi Tanaman Padi-Ternak Sapi Di Desa Jaro Kecamatan Jaro Kabupaten Tabalong (Studi Kasus Pada Kelompok Tani “Tani Membangun”). Ziraa'ah Majalah Ilmiah Pertanian, 42(2), 150-157.

Lukiwati, D. R., Karno -, \& Kristanto, B. A. (2016). Peningkatan Produksi Jagung Manis dan Jerami dalam Sistem Integrasi Tanaman Pangan dan Peternakan Sapi Brangus. Jurnal Ilmu Ternak Universitas Padjadjaran, 16(2), 89-94.

Marjaya, S. (2016). Analisis Efisiensi dan Daya Saing Komoditas pada Sistem Usahatani Integrasi Jagung-Sapi di Kabupaten Kupang. Ilmu Pertanian (Agricultural Science), 18(3), 164-174.

Merakati, Siswanto, U., Adiprasetyo, T., Purnomo, B., \& Nuri, L. (2017). The Suitability Of Different Sources Of Biofertilizers To Support Sustainability Of Organic Vegetables Practice In Bengkulu Province Of Indonesia. Agroecotechnology Department, Agriculture Faculty, University of Bengkulu. Indonesia., 3(12) 1-6.

Muchlis, D. \& Nurcholis. (2018). Sustainable Livestock Development In The Border Of Merauke Region Based On Environment. E3S Web of Conferences, 73, 03010. https://doi.org/10.1051/e3sconf/20187303010.

Muh Jurhadi Kadir. (2020). Analisis Pendapatan Sistem Pertanian Terpadu Integrasi PadiTernak Sapi Di Kelurahan Tatae Kecamatan Duampanua Kabupaten Pinran. Jurnal Ilmu dan Industri Peternakan, 6(1), 42-56. 
Mutmaidah, S. (2018). POTENSI Tanaman Pangan Dan Perkebunan Untuk Pengembangan Wilayah Kabupaten Kepahiang. JSEP (Journal of Social and Agricultural Economics), 11(3), 22-30.

Nazam, M., Sabiham, S., Pramudya, B., Widiatmaka, W., \& Rusastra, I. W. (2016). Penetapan Luas Lahan Optimum Usahatani Padi Sawah Mendukung Kemandirian Pangan Berkelanjutan di Nusa Tenggara Barat. Jurnal Agro Ekonomi, 29(2), 113-145.

Paramuji, M., \& Sunarti, T. C. (2012). Pengembangan Agroindustri Terpadu Sapi Potong-Jagung Berkelanjutan: Suatu Tinjauan Literatur. Jurnal Fakultas Teknik Universitas Pasir Pengaraian, 1(1), 1-10.

Prastyawan, R. M., Tampoebolon, \& Surono. (2012). Peningkatan Kualitas Tongkol Jagung Melalui Teknologi Amoniasi Fermentasi (Amofer) Terhadap Kecernaan Bahan Kering Dan Bahan Organik Serta Protein Total Secara In Vitro [Quality Improvement of Corn Cob by Ammoniation-Fermentation on Dry Matter. Animal Agriculture Journal, 1(1), 611-621.

Rocha de Moraes Rego, C. A., Ribeiro Reis, V. R., Wander, A. E., Cantanhêde, I. S. de L., Costa, J. B., Muniz, L. C., Costa, B. P., \& López de Herrera, J. (2017). Cost Analysis of Corn Cultivation in the Setup of the Crop-Livestock-Forest Integration System to Recover Degraded Pastures. Journal of Agricultural Science, 9(6), 168-175.

Ruhibnur, R., Aida, N., Susanto, A., Kurniawan, T., \& Rosmalinda, R. (2019). Optimalisasi Limbah Tongkol Jagung pada Pembuatan Bioetanol dan Karakteristiknya dengan Perlakuan Periode Fermentasi dan Konsentrasi Ragi. Jurnal Teknologi Agro-Industri, 6(2), 81-91.

Sari, A., Liman, \& Muhtarudin. (2016). Potensi Daya Dukung Limbah Tanaman Palawija Sebagai Pakan Ternak Ruminansia Di Kabupaten Pringsewu. Jurnal Ilmiah Peternakan Terpadu, $4(2), 11-21$.

Sariubang, M. (2010). Sistem Usahatani Terpadu Jagung dan Sapi di Kabupaten Takalar Provinsi Sulawesi Selatan. Prosiding Pekan Serealia Nasional, 508-512.

Sasoeng, A., Tilaar, W., \& Kalangi, J. K. J. (2020). Potensi Pengembangan Ternak Sapi Potong Rakyat Di Kecamatan Rainis Kabupaten Kepulauan Talaud. Agri-Sosioekonomi, 16(2), 291-300.

Seran, S. O. T., Oematan, G., \& Maranatha, G. (2020). Pengaruh lama proses fermentasi tepung tongkol jagung menggunakan EM4 terhadap kandungan bahan kering, Bahan organik dan protein kasar. Jurnal Peternakan Lahan Kering, 2(3), 1015-1021.

Suprihatin, M. P., \& Sukardi, T. C. S. (2018). Pengembangan Agroindustri Terpadu Sapi PotongJagung Berkelanjutan: Suatu Tinjauan Literatur. Jurnal APTEK, 10(2), 80-88.

Susanto, H. (2014). Kajian Komoditas Unggulan, Andalan Dan Potensial Di Kabupaten Grobogan. $1(3), 18-24$.

Suwarto, Aryanto, A. T., \& Effendi, I. (2019). Perancangan Model Pertanian Terpadu TanamanTernak dan Tanaman-Ikan di Perkampungan Teknologi Telo, Riau. Jurnal Agronomi Indonesia (Indonesian Journal of Agronomy), 43(2), 168-177.

Suwarto, S., \& Prihantoro, I. (2020). Study of Sustainable Corn Development through the Integration with Cow in Tuban, East Java. Jurnal Ilmu Pertanian Indonesia, 25(2), 232238.

Tarmizi, H. B., \& Safaruddin. (2015). Pengaruh Sistem Integrasi Padi Ternak (Sipt) Terhadap Peningkatan Pendapatan Petani Dan Dampaknya Terhadap Pengembangan Wilayah Di Kabupaten Serdang Bedagai. Jurnal Ekonom, 15(4), 163-172.

Tumewu, J. M., Panelewen, V. V. J., \& Mirah, A. D. P. (2014). Analisis Usaha Tani Terpadu Sapi Potong Dan Padi Sawah Kelompok Tani “Keong Mas" Kecamatan Sangkub, Kabupaten Bolaang Mongondow Utara (Studi Kasus). ZOOTEC, 34(2), 1-9.

Usman, U., Tirajoh, S., Baliadi, Y., \& Rauf, A. W. (2017). Kelayakan Usaha Tani Padi dan Sapi Potong Mendukung Pengembangan Sistem Integrasi Tanaman-Ternak di Kabupaten Merauke, Papua. Teknologi Peternakan dan Veteriner Mendukung Diversifikasi Sumber Protein Asal Ternak, 191-197.

Widhyawaty, N. P. (2019). Diversifikasi Hasil Pertanian Terintegrasi Dan Pendapatan Petani Peternak Di Desa Kerta Kecamatan Payangan Kabupaten Gianyar. Jurnal Manajemen Agribisnis (Journal Of Agribusiness Management), 7(2), 141-146. 
Wina, E., \& Yulistiani, D. (2012). Improving Microbial Protein Synthesis in the Rumen of Sheep Fed Fresh Tofu Waste by Crude Tannin Extract of Acacia mangium. JITV, 17(3), 207-214.

Zahara, D. A., Liman, \& Muhtarudin. (2016). Kapasitas Peningkatan Populasi Ternak Ruminansia Berdasarkan Potensi Limbah Tanaman Pangan Sebagai Pakan Ternak Di Kabupaten Lampung Selatan. Jurnal Ilmiah Peternakan Terpadu, 4(3),11-18.

Zakiatulyaqin, Z., Suswanto, I., Lestari, R. B., Setiawan, D., \& Munir, A. M. S. (2017). Income Over Feed Cost Dan R-C Ratio Usaha Ternak Sapi Melalui Pemanfaatan Limbah Kelapa Sawit. Jurnal Ilmiah Peternakan Terpadu, 5(1), 18-22.

Zebedeus ., D., Kaunang, C. L., \& Tulung, Y. L. R. (2018). Potensi Pengembangan Ternak Sapi Potong Dengan Pola Integrasi Kelapa-Sapi Di Kecamatan Tabaru Kabupaten Halmahera Barat. Agri-Sosioekonomi, 14(1), 335-346. 